\title{
Targeting Tyro3, Axl and MerTK (TAM receptors): implications for macrophages in the tumor microenvironment
}

\author{
Kayla V. Myers ${ }^{1,2^{*}}$ (D, Sarah R. Amend ${ }^{2}$ and Kenneth J. Pientata,2,3,4
}

\begin{abstract}
Tumor-associated macrophages are an abundant cell type in the tumor microenvironment. These macrophages serve as a promising target for treatment of cancer due to their roles in promoting cancer progression and simultaneous immunosuppression. The TAM receptors (Tyro3, Axl and MerTK) are promising therapeutic targets on tumor-associated macrophages. The TAM receptors are a family of receptor tyrosine kinases with shared ligands Gas6 and Protein S that skew macrophage polarization towards a pro-tumor M2-like phenotype. In macrophages, the TAM receptors also promote apoptotic cell clearance, a tumor-promoting process called efferocytosis. The TAM receptors bind the "eat-me" signal phosphatidylserine on apoptotic cell membranes using Gas6 and Protein S as bridging ligands. Post-efferocytosis, macrophages are further polarized to a pro-tumor M2-like phenotype and secrete increased levels of immunosuppressive cytokines. Since M2 polarization and efferocytosis are tumorpromoting processes, the TAM receptors on macrophages serve as exciting targets for cancer therapy. Current TAM receptor-directed therapies in preclinical development and clinical trials may have anti-cancer effects though impacting macrophage phenotype and function in addition to the cancer cells.
\end{abstract}

Keywords: Macrophage, TAM receptors, Tyro3, Axl, MerTK, Efferocytosis, M2 macrophage polarization

\section{Background}

Cancer is one of the leading causes of death worldwide. In the United States, $1,762,450$ new cases and 606,880 cancer-related deaths are estimated to occur in 2019 [1]. Disease progression is strongly influenced by the tumor microenvironment (TME), comprised of all host cells and components beyond the cancer cells [2-5]. The TME is made of blood vessels, extracellular matrix (ECM) and many different host cell types including fibroblasts, B cells, and T cells. Tumor-associated macrophages are a critical component of the TME. In general, these macrophages have tumor-promoting functions such as tumor initiation, growth, angiogenesis, metastasis, immunosuppression and resistance to therapy [6]. Elucidating the role of macrophages in tumor biology is

\footnotetext{
* Correspondence: kmyers38@jhmi.edu

'Department of Pharmacology and Molecular Sciences, The Johns Hopkins School of Medicine, Baltimore, MD, USA

${ }^{2}$ The James Buchanan Brady Urological Institute, Department of Urology, The Johns Hopkins School of Medicine, Baltimore, MD, USA

Full list of author information is available at the end of the article
}

crucial as modulating their activity may open new opportunities for therapeutic interventions. Likewise, it is also important to understand how macrophages in the TME are impacted by current therapies aimed at targeting cancer cells.

Macrophages have diverse roles under normal physiologic conditions including phagocytosis, antigen-presentation and modulation of the immune response [7, 8]. There are different subtypes of macrophages that play unique and related roles in both normal and disease states. M2 macrophages support tissue homeostasis, wound-healing and resolution of inflammation. Tumor-associated macrophages are largely polarized to an alternatively-activated, M2-like state. In the TME, M2-like macrophages exert pro-tumor effects via their wound-healing functions. For example, M2 macrophages promote angiogenesis through secretion of pro-angiogenic factors $[9,10]$. M2 macrophages suppress $\mathrm{T}$ cell infiltration and cytotoxic $\mathrm{T}$ cell function which impairs the anti-tumor immune response [11-13]. M2 tumor-associated macrophages also promote invasion and metastasis of cancer cells through ECM remodeling [14].

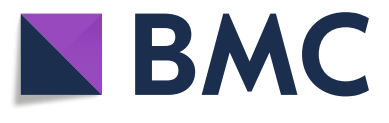

(c) The Author(s). 2019 Open Access This article is distributed under the terms of the Creative Commons Attribution 4.0 International License (http://creativecommons.org/licenses/by/4.0/), which permits unrestricted use, distribution, and reproduction in any medium, provided you give appropriate credit to the original author(s) and the source, provide a link to the Creative Commons license, and indicate if changes were made. The Creative Commons Public Domain Dedication waiver (http://creativecommons.org/publicdomain/zero/1.0/) applies to the data made available in this article, unless otherwise stated. 
Another M2-associated function is phagocytosis of apoptotic cells, i.e., efferocytosis. Efferocytosis is enacted to resolve inflammation, repair tissue and suppress the immune system. In the TME, these effects promote tumor growth, metastasis and evasion of anti-tumor immunity [15, 16]. Thus, targeting tumor-associated macrophages and their function are potential therapeutic strategies due to their large influence in disease progression.

The TAM receptors (Tyro3, Axl and MerTK) are a well-studied family of receptors that, in addition to their function in many other cell types, including cancer cells, play roles in macrophage polarization and efferocytosis. The role of the TAM receptors in macrophages was first discovered upon the generation of TAM receptor single, double and triple knockout mice [17]. At approximately 4 weeks of age, the spleens and lymph nodes of the triple knockout mice were substantially larger compared to wild type (WT) mice due to hyperproliferation of constitutively active $\mathrm{B}$ and $\mathrm{T}$ lymphocytes. The triple knockout mice also developed autoimmune diseases such as rheumatoid arthritis and system lupus erythematosus [18]. These phenotypes were found to be due to altered macrophage and dendritic cell function. Following this work, the role of the TAM receptors on macrophages in different tissues and disease states has been studied. This review will summarize macrophage TAM receptor function in the context of the TME and discuss implications for interventions in cancer therapy.

\section{Main text}

\section{The TAM receptor family and their ligands}

The TAM receptor family is comprised of three receptor tyrosine kinases that share similar structures distinct from other receptor tyrosine kinases (Fig. 1a). Each receptor's extracellular domain contains two immunoglobulin-like (IgL) repeats and two fibronectin type III (FNIII) repeats. This is followed by a single helix transmembrane domain and the cytoplasmic tyrosine kinase domain (TKD) containing the KW(I/L)A(I/L)ES consensus sequence [19]. Axl was the first of this family discovered in studies identifying genes that transform NIH 3 T3 cells [20, 21]. MerTK was originally identified as the oncogene v-ryk from avian retroviruses and recognized as a member of the Axl family when the murine form was cloned [22, 23]. Tyro3 was the last of the three proteins to be added to the TAM receptor family based on its shared homology [24]. There are multiple alternative names for each in the published literature, and for clarity the names Tyro3, Axl and MerTK will be used throughout this review regardless of the naming convention used in the referenced literature. Axl is also known as UFO, Tyro7, JTK11 and ARK. MerTK is also referred to as MER, RP38, c-Eyk, c-mer, and Tyro12. Tyro3 can also be called RSE, BYK, Etk-2, Dtk, Rek, Sky and Tif.
The TAM receptors are activated upon binding of their extracellular ligands. Gas6 and Protein S were the first discovered and are the most studied ligands for the TAM receptors. Gas6 was identified as one of the upregulated "growth arrest-specific" genes following serum starvation of NIH 3 T3 cells [25]. Gas6 was then confirmed in humans and recognized to have strong homology with Protein S [26, 27]. Protein S, also known as Pros1, is a Vitamin $\mathrm{K}$ dependent protein that has TAM receptor-independent roles in the blood coagulation cascade $[28,29]$. As depicted in Fig. 1b, the amino terminus Gas6 and Protein S have a $\gamma$-carboxyglutamic acid (Gla) domain followed by four epidermal growth factor (EGF)-like repeats. Adjacent to the carboxy terminus are two laminin G (LG)-like domains that share sequence similarity to the sex hormone-binding protein (SHBP) [27]. Unique to Protein $S$ is a thrombin sensitive cleavage site between the Gla and EGF-like domains [30]. While at first unclear, it is now understood that Gas6 binds all three receptors, whereas Protein S only activates Tyro3 and MerTK [27, 31-33]. There are three newly discovered ligands of the TAM receptors: Tubby and galectin-3, which bind MerTK, and Tubby-like protein 1 (Tulp-1) which binds all three receptors [34-36]. Due to the recentness of these TAM receptor ligand discoveries, not much as much information regarding their function is known compared to that of Gas6 and Protein $\mathrm{S}$ and this review will largely focus on the effects of ligands Gas6 and Protein S.

\section{TAM receptor-mediated signaling}

Consistent with other receptor tyrosine kinases (RTKs), the TAM receptors become activated following ligand binding, receptor dimerization and subsequent trans-autophosphorylation of the kinase domains to activate intracellular signaling cascades and modulate gene transcription. More specifically, the TAM receptors are activated upon IgL domain binding to the LG-like domains of their ligand [37, 38]. Prior to activation, glutamic acid $\gamma$-carboxylation of the Gla domain the ligand Gas6 or Protein S is required [39].

The lipid membrane molecule phosphatidylserine (PtdSer) has been shown to strengthen ligand binding affinity and TAM receptor mediated signal transduction [40-43]. This interaction occurs when PtdSer binds to the Gla domain of Gas6 or Protein S in the presence of $\mathrm{Ca}^{2+}$ ions $[40,44]$. In this context Gas6 and Protein $\mathrm{S}$ serve as bridging molecules for PtdSer and the TAM receptor. Adding PtdSer containing lipid membranes in the presence of TAM receptor ligand increases phosphorylation levels of TAM receptors compared to just adding ligand alone [41, 42]. This bridging interaction and signaling is important for phagocytosis of apoptotic cells exposing PtdSer. 


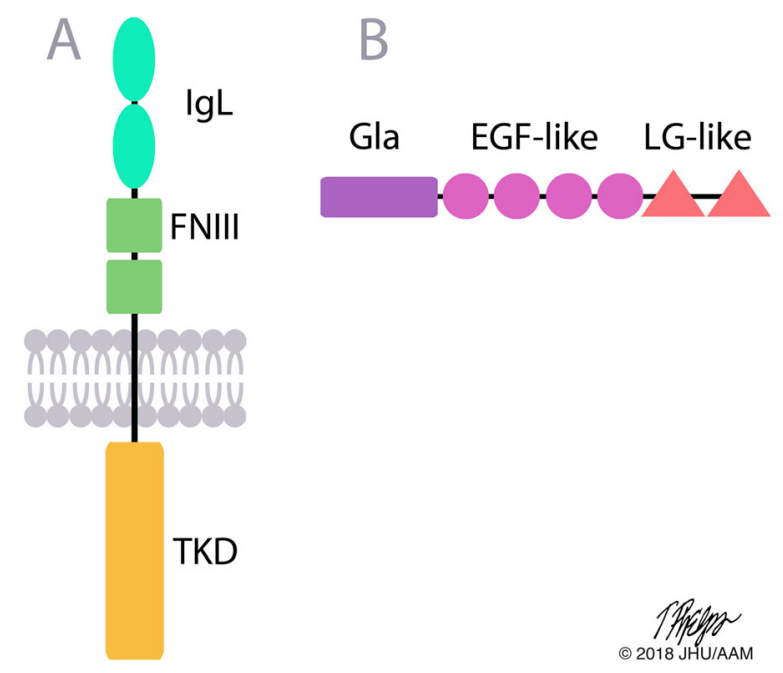

Fig. 1 The structure of the TAM receptors and their shared ligands Gas6 and Protein S. a Tyro3, Axl and MerTK share a similar structure of two IgL domains, two FNIII domains and an intracellular TKD. b Gas6 and Protein S contain a Gla domain, four EGF-like domains and two LG-like domains. Abbreviations: IgL = immunoglobulin-like, FNIII = fibronectin type III, TKD = tyrosine kinase domain, Gla = $\gamma$-carboxyglutamic acid, EGF = epidermal growth factor, LG-like = laminin G

There are a wide variety of complex downstream signaling pathways following TAM receptor phosphorylation. Detailed reviews summarizing known signaling pathways of individual TAM receptors have been published $[19,45,46]$. One of the most well characterized TAM receptor signaling pathways in macrophages is the phosphoinositide 3 kinase (PI3K)/Akt pathway. PI3K is made of a p 85 regulatory subunit and a p110 catalytic subunit [47]. The intracellular kinase domain of phosphorylated Tyro3, Axl and MerTK can bind the p85 subunit of PI3K directly $[48,49]$. Alternatively, the TAM receptors can also interact with p85 using growth factor receptor-bound protein 2 (Grb2) as a bridging protein $[48,50,51]$. Following activation of PI3K through either mechanism, PI3K phosphorylates Akt. In U937-derived macrophages, it has been shown that Gas6 mediated phosphorylation of Akt leads to glycogen synthase kinase $3 \beta$ (GSK3 $\beta$ ) phosphorylation and suppression of NF- $k B$ nuclear translocation, thereby altering gene transcription [52]. The PI3K/Akt signaling axis has been shown to play roles in macrophage activation and polarization, suggesting a tole for the TAM receptors in regulating macrophage phenotype and function $[53,54]$.

\section{TAM receptor expression is influenced by macrophage polarization}

Macrophages are influenced by cytokines and factors to adopt various phenotypes and functions. "Classically activated" M1 macrophages are involved in defense against bacteria and viruses and polarize in response to granulocyte-macrophage colony stimulating factor (GM-CSF), interferon- $\gamma$ (IFN- $\gamma)$ and microbial products such as lipopolysaccharide (LPS). These macrophages secrete pro-inflammatory cytokines and factors such as tumor necrosis factor $\alpha$ (TNF- $\alpha$ ), interleukin-6 (IL-6), IL-1 $\beta$, IL-12, IL-15, IL-18 and nitric oxide (NO). "Alternatively activated" M2 macrophages are stimulated by factors such as macrophage colony-stimulating factor (M-CSF), IL-4, IL-13, IL-10 and dexamethasone. Secreted products of M2 macrophages include transforming growth factor $\beta$ (TGF- $\beta$ ), IL-10, IL-13 and IL- $1 \alpha$. Through their functions and cytokine production, M2 macrophages have roles in tissue homeostasis, wound healing and fighting parasitic infections. In the setting of the TME, M1 macrophages play anti-tumor roles that aid in tumor immunity and M2 macrophages have pro-tumor influences that support disease progression.

Monocytes are differentiated into macrophages which are then polarized to different subtypes. Upon monocyte to macrophage differentiation, MerTK expression is upregulated and Tyro3 levels remain unchanged [55-57]. There is conflicting evidence regarding Axl expression, with reports of both increased and decreased expression upon monocyte differentiation to macrophages $[55,56]$. While Tyro3 mRNA and protein are expressed in monocytes and macrophages, there is a lack of literature characterizing Tyro3 expression levels on macrophages polarized to either an M1 or M2 subtype. However, Axl and MerTK expression on M1-like and M2-like macrophages has been described in the literature and will be summarized here.

Like the evidence for monocyte-to-macrophage differentiation, there is conflicting evidence in the literature regarding Axl expression on M1-like and M2-like macrophages. Several reports have demonstrated Axl expression to be higher on M2-like macrophages. Axl 
expression is increased in IL-4 and IL-13 polarized M2 macrophages compared to LPS and IFN- $\gamma$ M1 polarized macrophages in murine bone marrow-derived macrophages (BMDMs) [58]. AXL transcripts levels are higher in M2-like human monocyte-derived macrophages polarized with M-CSF than M1-like polarized with GM-CSF [59]. In human monocyte-derived macrophages, $A X L$ mRNA is induced following treatment with immunosuppressive M2-stimulant dexamethasone [56]. In contrast, however, there is also evidence that Axl expression is higher on M1-like macrophages. Following treatment with M1-stimulant LPS, BMDMs have increased Axl expression [41]. This study also observed Axl downregulation following dexamethasone treatment to induce M2-like macrophages. Pro-inflammatory viral triggers such as IFN- $\alpha$ and poly(I:C) also stimulate Axl expression on human monocyte-derived macrophages $[41,60]$. Thus, it is possible that Axl expression on M1 versus M2 macrophages may differ model-to-model based on specific experimental conditions, such as source of monocytes and method of polarization.

MerTK expression has consistently been shown to be higher in immunosuppressive, M2-like macrophages than unstimulated and M1-like macrophages. It has been reported that Mertk mRNA transcript levels are higher in IL-4 and IL-13 M2 polarized BMDM's than LPS and IFN- $\gamma$ M1 polarized BMDM's [58]. Monocyte-derived human macrophages treated with M2-stimulants M-CSF, IL-4, IL-10 or CD5L have higher MerTK protein levels than untreated macrophages or those stimulated with M1-stimulant GM-CSF, LPS, IFN- $\gamma$, IFN- $\alpha$ or poly (I:C) [60-63]. MerTK is also upregulated in human monocyte-derived macrophages following stimulation with dexamethasone and corticosteroids hydrocortisone and aldosterone, supporting MerTK expression in immunosuppressive, anti-inflammatory M2-like macrophages $[41,56,60,62,64]$.

\section{TAM receptor signaling inhibits M1 polarization and induces $\mathrm{M} 2$ polarization}

While LPS and IFN- $\gamma$ are the standard M1 macrophage inducers and IL-4 and IL-13 are the standard M2 macrophage polarizing agents for in vitro polarization, there are many other proteins and stimulants that can skew macrophage polarization. TAM receptor signaling has been shown to play a role in shifting macrophage polarization by dampening M1 polarization and inducing M2 polarization (Fig. 2).

TAM receptor signaling has been shown to reduce M1 polarization, with most evidence showing a decrease in M1-associated cytokine secretion (e.g.; TNF- $\alpha$, IL-6 and IL-1ß) following TAM receptor activation by Gas6 or Protein S. In LPS-stimulated U937-derived macrophages, Gas6/MerTK signaling decreases secretion levels of TNF- $\alpha$, IL-6 and IL-1 $\beta$ [52]. Similarly, Gas6/MerTK signaling inhibits TNF- $\alpha$ and IL- 6 secretion in human monocytes/macrophages [52]. In an independent study, MerTK activation was shown to inhibit TNF- $\alpha$ production by LPS-stimulated mouse macrophages [65]. Additionally, exogenous Gas6 treatment on phorbol 12-myristate 13-acetate (PMA)-differentiated THP-1 macrophages decreases TNF- $\alpha$, IL- $1 \beta$ and IL- 6 mRNA and protein levels, providing further evidence that TAM receptor signaling blocks M1 polarization [66]. It has been shown that Protein S activation of either MerTK or Tyro3 inhibits LPS and IFN- $\gamma$ induced M1 polarization of peritoneal and tumor-derived mouse macrophages, indicated by decreased expression of M1 marker genes Il1, Il6, Cd86 and Tnf [67]. Stimulation of mouse peritoneal macrophages with Gas6 or Protein S decreases M1-associated inflammatory gene expression of IL-1 $\beta$, IL-6 and TNF- $\alpha$ [68]. Additionally, inhibition of Gas6 or Protein $S$ with neutralizing antibodies increases expression levels of these M1-associated pro-inflammatory genes [68]. In an invasive pulmonary aspergillosis (IPA) model, it has been shown that an anti-Axl antibody increases the number of M1 macrophages [69]. This was measured by an increase whole-lung Inos transcript levels, a marker of M1 activation and a decrease in M2 activation markers Arg1 and Fizz1. Contradictory to these studies, inhibition of Axl with a monoclonal antibody has been shown to decrease M1-associated inflammatory factors IL-6, TNF- $\alpha$ and G-CSF production by tumor associated macrophages in MDA-MB-231 xenograft breast cancer models, suggesting Axl promotes M1 polarization some cases [70].

In addition to effects on M1 polarization, TAM receptor signaling has also been shown to promote pro-tumor M2 macrophage polarization. Gas6 mediated MerTK signaling in the RAW264.7 murine macrophage cell line increases mRNA and protein levels of M2-associated genes Arg2 and VEGF, as well as mRNA levels of Arg1 [71]. Recently, it was discovered that mineral trioxide aggregate (MTA) polarizes THP-1 cells towards an M2 phenotype in an Axl signaling-dependent manner. The MTA-induced M2 polarization, indicated by increased M2 marker CD206 and M2-associated secreted cytokines IL-10, TGF- $\beta$ and VEGF was blocked by the Axl small molecule inhibitor R428 [72]. M1 polarized THP-1 macrophages treated with Gas6 have increased protein levels of the M2 marker CD206 and mRNA levels of M2-associated genes CD206 and IL10 [73]. These macrophages also have decreased protein levels of M1 marker CD11b and increased STAT6 phosphorylation, an inducer of M2 polarization. Mice null for Galectin-3, a newly discovered MerTK ligand, have a reduced IL-4 and IL-13 induced M2 polarization, suggesting galectin-3 also skews macrophage polarization towards 


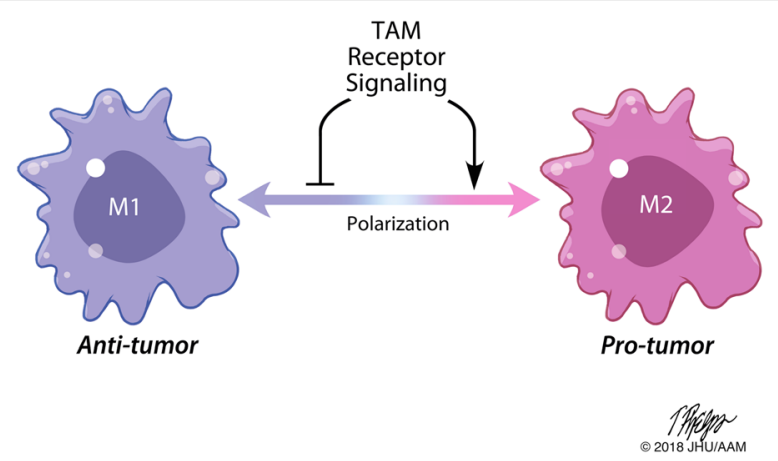

Fig. 2 TAM receptor signaling skews macrophage polarization. TAM receptor binding and downstream signaling dampens M1 polarization and promotes M2 polarization. Overall, this decreases anti-tumor M1-like phenotypes and functions and increases pro-tumor M2-like phenotypes and functions

an M2-like phenotype [74]. Taken together, these data suggest that the TAM receptors play a role in shifting macrophage polarization away from an M1-like phenotype and towards an M2-like phenotype.

Efferocytosis and M2-like polarization is tumor-promoting A major role of macrophages is clearance of apoptotic cells, a process known as efferocytosis. Dendritic cells and specialized epithelial cells and fibroblasts also have the ability to efferocytose. This mechanism is enacted to maintain tissue homeostasis and prevent induction of inflammation by secondary necrosis. Under normal physiology, lack of efferocytosis is disadvantageous in many cases because secondary necrosis releases immunogenic components that can lead to chronic inflammation and autoimmune disorders [75]. However, in a cancer setting efferocytosis is pro-tumor as it induces a wound-healing immunosuppressive phenotype. Consistent with this phenotype, M2-like macrophages have a greater capacity for efferocytosis than M1-like macrophages [60, 76-79]. Due to its tumor-promoting role, the efferocytosis pathway is an exciting and new potential therapeutic target [16].

Efferocytosis is initiated by signals from the apoptotic cell that then promote cytoskeletal rearrangement and nuclear receptor signaling in the efferocytosing macrophage. "Find-me" signals promote attraction of monocytes and macrophages. Some well-established "find-me" signals are adenosine triphosphate (ATP), uridine triphosphate (UTP), lysophosphatidylcholine (LPC), fractalkine and spingosine 1-phosphate (S1P) which are released from the cell in a caspase-regulated manner during apoptosis [80-83]. Apoptotic cells also display "eat-me" signals on their surface for macrophages to tether to. The most characterized "eat-me" signal is the lipid moiety PtdSer. Healthy cells sequester PtdSer on the inner leaflet by action of flippase enzymes. During apoptosis, caspase activity inactivates the flippase adenosine triphosphatase type $11 \mathrm{C}$ (ATP11C) and activates the scramblase Xk-Related Protein 8 (Xkr8) allowing PtdSer exposure on the outer leaflet of the cell membrane [84, 85].

The TAM receptors, among others such as phosphatidylserine receptor (PSR), CD36, Tim4, BAI1 and $\alpha_{v} \beta_{3}$ integrin bind PtdSer to tether the macrophage to the apoptotic cell [86-91]. As discussed in a previous section, Gas6 and Protein S serve as bridging molecules between PtdSer and the TAM receptors (Fig. 3). PtdSer binds the Gla end of Gas6 and Protein S while the TAM receptors bind their LG domains. This allows macrophages to attach to the apoptotic cell prior to phagocytosis [92].

Following TAM receptor apoptotic cell tethering, cytoskeletal rearrangements induce phagocytosis. Evidence for the mechanism of cytoskeletal rearrangement by MerTK-mediated efferocytosis has been described. Following apoptotic cell binding, the phosphorylated tyrosine kinase domain of MerTK facilitates phosphorylation of Vav1 [93]. The binding of the cytoplasmic tail to Vav1 is phosphotyrosine-independent, although MerTK activation is required for Vav1 phosphorylation and release. Vav1 is a guanine nucleotide-exchange factor (GEF) that can stimulate guanosine diphosphate (GDP) to guanosine triphosphate (GTP) exchange. When phosphorylated, Vav1 activates Rho family members Rac1, Cdc42 and RhoA [93, 94]. These proteins temporally and spatially regulate cytoskeleton dynamics, which promote engulfment of the apoptotic cell [95-97].

Following engulfment of apoptotic cells, nuclear receptors are engaged in response to an increase in metabolic demand from the ingested cellular components (Fig. 4). Specifically, retinoid X receptors (RXRs) form heterodimers with peroxisome proliferator activated receptors (PPARs), and liver X receptors (LXRs) that have important roles in efferocytosis and other macrophage functions $[98,99]$. These nuclear receptors have been shown to be associated with transcription of genes controlling and associated with M2 polarization [100-104]. This 


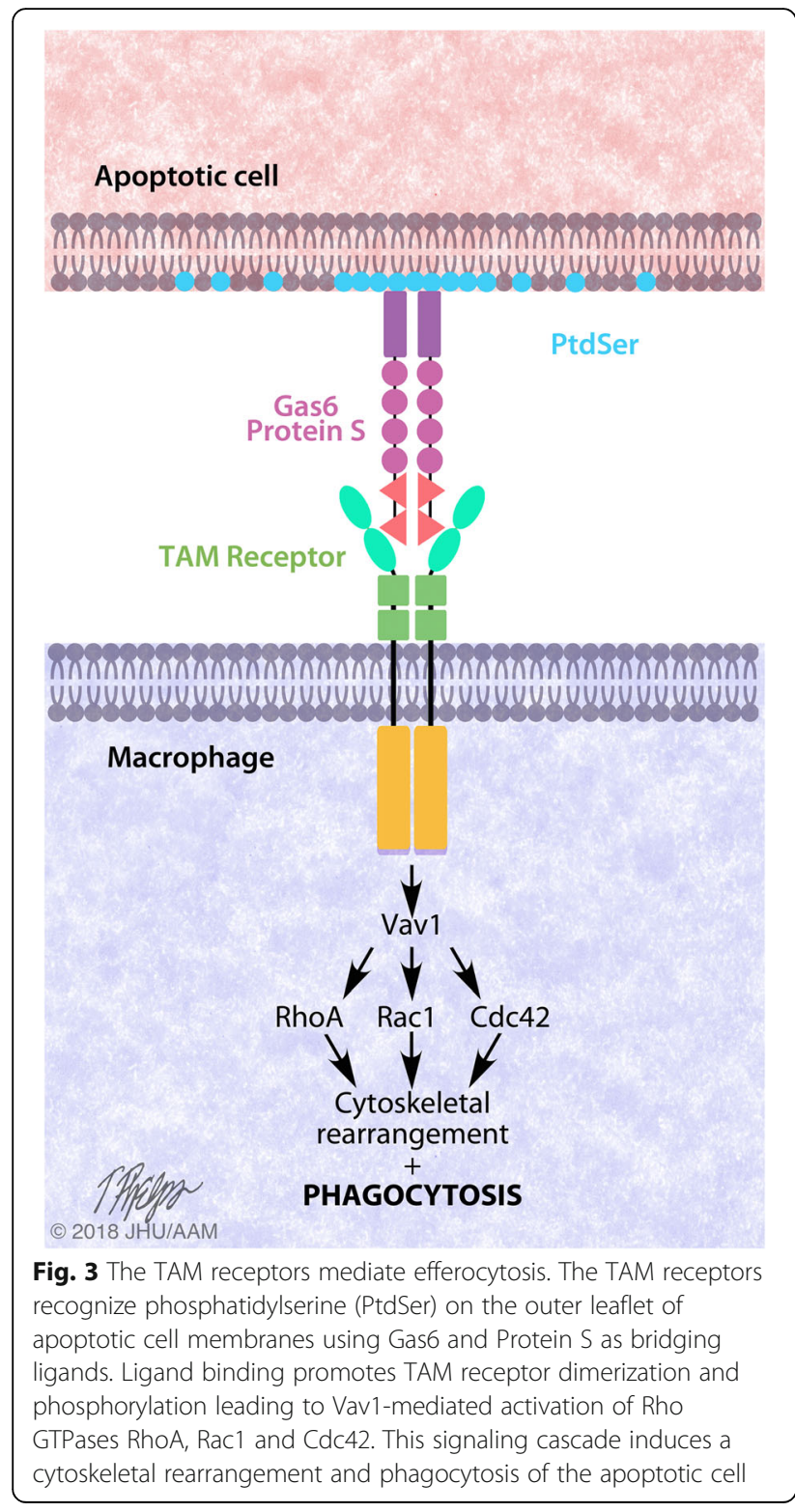

evidence suggests that nuclear receptor signaling following efferocytosis further polarizes macrophages to an M2-like phenotype. Notably, the process of efferocytosis itself promotes increased secretion of immunosuppressive cytokines associated with M2-like macrophages such as IL-10, TGF- $\beta$, IL-4 [105-107]. Apoptotic cell clearance by macrophages also decreases secretion of immune-stimulating cytokines associated with M1-like macrophages such as TNF- $\alpha$, IL- $1 \beta$ and IL-12 [105, 107]. This evidence indicates that efferocytosis further promotes M2 polarization and function that can drive disease progression.

Nuclear receptors also regulate gene expression of machinery necessary for efferocytosis such as MERTK and $A X L$. PPAR- $\delta$, PPAR $-\gamma$ and RXR $\alpha$ have been shown to increase MERTK and $A X L$ transcription in macrophages [108-111]. Pharmacologic inhibition or knockout of these nuclear receptors impairs apoptotic cell phagocytosis. However, in a separate study, MerTK and Gas6 expression was shown to increase with a PPAR- $\gamma$ antagonist [112]. This conflicting evidence may reveal a further layer of MerTK regulation by nuclear receptors depending on the macrophage phenotype. Following apoptotic cell phagocytosis, LXR signaling is also induced [113]. MERTK, but not TYRO3 or AXL, is a direct target gene of LXR nuclear receptors. As a result, $M E R T K$ transcription is increased following efferocytosis, creating a positive feedback loop. It has also been shown that MerTK signaling increases LXR abundance, which could potentiate this loop further [114].

One of the non-cytokine secreted products following apoptotic cell clearance by macrophages is hepatocyte growth factor (HGF) [115]. Shown in RAW 264.7 cells, this increase in HGF production was found to be mediated by MerTK (but not Axl or Tyro3) activation via RhoA-mediated signaling [116, 117]. Gas6/MerTK stimulated HGF production was found involve the same signaling pathway and was able to stimulate wound repair and cell growth of LA-4 epithelial cells [118]. While these studies speculated implications with alveolar macrophages, it remains of interest if these findings can translate to tumor associated macrophages since HGF can promote disease through $\mathrm{HGF} / \mathrm{c}-$ Met signaling in a number of cancers [119].

While all three TAM receptors mediate efferocytosis in macrophages MerTK has been found to be essential to the process. MerTK was first identified as a phagocytotic receptor when it was observed that Mertk deficient mice had dramatically reduced clearance of apoptotic thymocytes [120]. While apoptotic cell clearance by macrophages is nearly abolished in Mertk deficient mice, it is also substantially decreased in $A x l$ and Tyro3 single knockout mice [57]. Additionally, RAW264.7 macrophages treated with an anti-MerTK antibody have impaired phagocytosis of apoptotic thymocytes [113]. Although Axl and Tyro3 mediate efferocytosis in macrophages, they may play more dominant roles in efferocytosis by dendritic cells $[57,121]$. It has also been proposed that macrophage efferocytosis is dominated by MerTK in an immunosuppressive setting, whereas Axl is important in an inflammatory setting, dominating efferocytosis [41].

\section{TAM receptor inhibition as a therapy for cancer}

Given what is known about the role of the TAM receptors in macrophages, key members of the TME, TAM receptor inhibition is a strong candidate for an anti-cancer therapy. TAM receptor inhibition may impair pro-tumor effects of M2-like macrophages by blocking efferocytosis. 

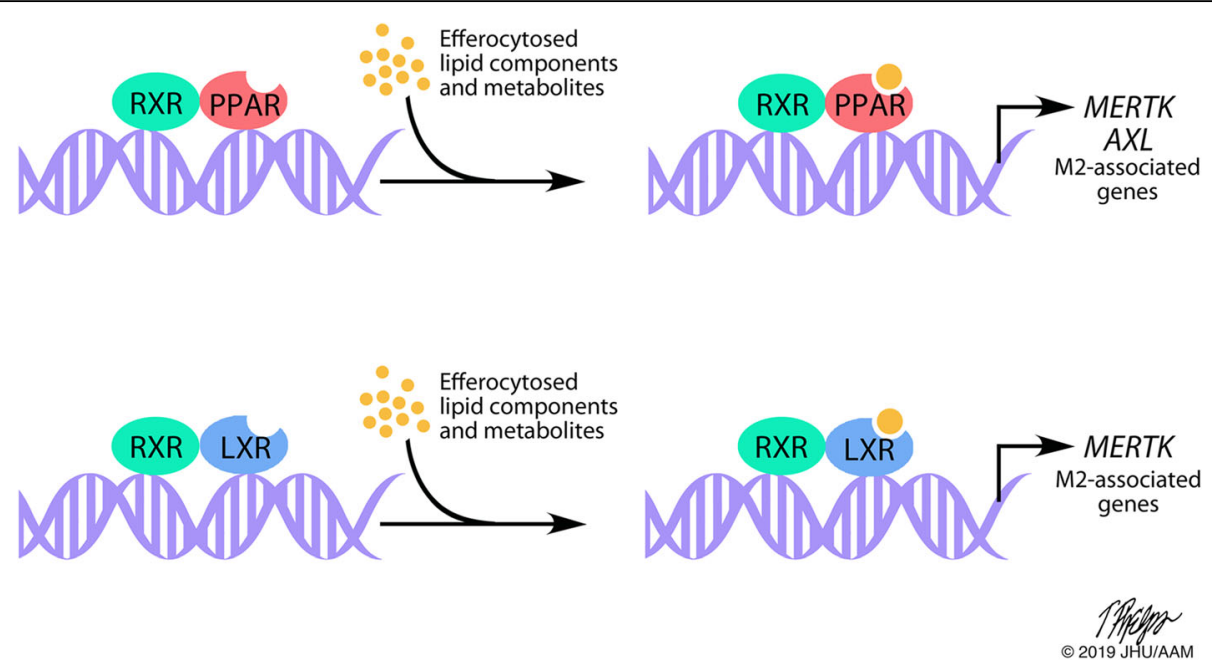

Fig. 4 Nuclear receptors regulate gene transcription post-efferocytosis. PPARs and LXRs form heterodimers with RXRs to regulate gene transcription. Following efferocytosis, lipid components and metabolites from the apoptotic cell bind PPARs and LXRs. These activated nuclear receptors act as transcription factors to upregulate MERTK, AXL and M2-associated gene expression

Since TAM receptor activation also skews macrophages polarization from an M1 to M2 phenotype, TAM receptor inhibition would decrease M2 characteristics of tumor-associated macrophages. As M2 macrophages have tumor-promoting roles involving cancer progression and immune suppression, impairing M2 polarization will slow disease progression. In addition to dampening M2 polarization, TAM receptor inhibition will increase polarization of M1-like macrophages in the TME. Since M1 macrophages have anti-tumor functions, shifting the balance of macrophages towards an M1 phenotype is beneficial in cancer. For example, in ovarian cancer the ratio of M1 to M2 tumor-associated macrophages decreases with increasing cancer stage, and a high ratio correlates with increased survival [122]. Similarly, pediatric classical Hodgkin Lymphoma patients with a predominant M1 polarization have a better overall survival [123].

There have been a few studies showing that MerTK inhibition, specifically on macrophages, is an effective anti-cancer therapy. In a number of different cancer types and tumor models, there is increased tumor macrophage infiltration following radiation therapy and these macrophages have been suggested to confer radioresistance to cancer cells [124-126]. MerTK on tumor associated macrophages has been shown to play a role in radiation therapy resistance. Following radiation therapy in a colorectal cancer mouse model, MerTK, Protein S and Gas6 are upregulated in tumor associated macrophages [127]. Neither Axl nor Tyro3 expression are changed. In this study Mertk knockout mice had a stronger overall survival following radiation therapy than wild type mice. This suggests that targeting MerTK on tumor associated macrophages may impair resistance following radiation therapy.

Inhibition of MerTK on leukocytes decreases tumor growth and metastasis in in vivo models of breast cancer, melanoma and colon cancer [128]. Mertk knockout mouse had decreased levels of the wound-healing cytokine IL-10 and increased levels of inflammatory cytokines IL-12 and IL- 6 levels. Specific to the CD11b+ macrophage population, IL-6 expression was increased compared to the WT mice. These changes in cytokine expression indicates a more M1-like macrophage phenotype. These Mertk knockout mice also had higher levels of CD8+ T cells following tumor inoculation, suggesting the change in cytokine expression may help promote anti-tumor immunity. This suggests that targeting MerTK on leukocytes, including macrophages, has multiple arms of anti-cancer activity.

In addition to impacting macrophage polarization and function, the TAM receptors have been shown to drive disease progression through their direct roles in growth, migration and therapy resistance of cancer cells. In certain cell line and mouse models for glioma, Kaposi sarcoma, mesothelioma, and non-small cell lung cancer, Axl inhibition decreases tumor growth [129-132]. Tyro3 is a proposed target in ovarian cancer due to its role in taxol resistance [133]. Additionally, siRNA silencing of Tyro3 has been shown to reduce proliferation in breast cancer cell lines [134, 135]. In non-small cell lung cancer, MerTK expression correlates with chemotherapy resistance, proliferation and migration [132, 136]. Thus, for some cancers the TAM receptors may serve as a strong dual target to impair both the tumor cells as well as tumor-associated macrophages. 
Due to similarities in structure in the three TAM receptors, it is difficult to develop inhibitors specific for a single TAM receptor. Some TAM receptor inhibitors have specificity for other RTKs. However, targeting multiple TAM receptors may be advantageous as MerTK upregulation as a result of silencing or inhibiting Axl has been observed in several cancer models, suggesting the MerTK mediates resistance to treatments targeting Axl [137]. Additionally, as all three TAM receptors mediate M2 polarization and efferocytosis by macrophages, targeting multiple TAM receptors may have a stronger anti-cancer effect.

R428 is a small molecule inhibitor of Axl widely used in preclinical studies and in a number of clinical trials (see Table 2). While this inhibitor most potently inhibits Axl, there is off-target inhibition of other kinases including MerTK and Tyro3 [138]. R428 has demonstrated anti-cancer activity in a number of preclinical studies. For example, R428 decreases invasion and growth of the esophageal adenocarcinoma cell line OE33, as well as increases sensitivity to Lapatinib [139]. This inhibitor also induces apoptosis in freshly isolated B-cell chronic lymphocytic leukemia and at high doses overcomes stroma-mediated protection [140]. R428 blocks growth and migration of erlotinib resistant tongue squamous cell carcinoma HN5 cells [141]. Axl is overexpressed in metformin resistance prostate cancer LNCaP cells and Axl inhibition with R428 re-sensitized these resistant cells to metformin [142]. In vivo, R428 slows tumor growth of mice subcutaneously injected with chronic myeloid leukemia (CML) cell lines [143]. It has also been shown that R428 in combination with paclitaxel reduces proliferation of uterine serous cancer xenograft models [144]. While these studies focused on the effect of R428 on cancer cells and disease progression, it remains unknown if R428 inhibition of Axl on macrophages contributed to the positive results in these studies. Other Axl inhibitors are currently being used in preclinical studies and demonstrate therapeutic effects utilizing in vitro and in vivo cancer models (see Table 1).

Several MerTK inhibitors are also in development (see Table 1). UNC569, UNC1062, UNC1666, UNC2025 and UNC2250 are MerTK small molecule inhibitors that have demonstrated anti-cancer activity in preclinical models [145-150]. UNC569 induces apoptosis, improves sensitivity to cytotoxic chemotherapy and reduces colony formation in ALL cell lines [146]. UNC569 has also been utilized in vivo to study phagocytosis by retinal pigment epithelium cells [151]. UNC1062, as well as UNC569, induces apoptosis and decreases cell growth in AML cell lines [147]. UNC1666 is a dual MerTK and FLT3 inhibitor that reduces colony formation in MerTKor FLT3-ITD- expressing AML cell lines [148]. UNC1062 and UNC1666 have poor oral bioavailability, so their clinical utility may be limited $[148,149]$. UNC2025 is an orally bioavailable dual MerTK and

Table 1 Summary of TAM receptor inhibitors in preclinical studies

\begin{tabular}{|c|c|c|}
\hline TAM Targeting Drug (Drug Type) & Target(s) & Outcomes in cancer models \\
\hline $\begin{array}{l}\text { 2,4-diaminopyrimidine-5-carboxamide analogs } \\
\text { (Small molecule) }\end{array}$ & Tyro3 & Not reported. \\
\hline "Compound 47" (Small molecule) & $\begin{array}{l}\text { Tyro3, IGF-1R, } \\
\text { EphA2 }\end{array}$ & Anti-cancer properties in HCC cell lines and xenograft models [158]. \\
\hline DP-3975 (Small molecule) & Axl & Anti-cancer properties in mesothelioma cell lines [131]. \\
\hline GL21.T (RNA aptamer) & Axl & $\begin{array}{l}\text { Anti-cancer properties in a glioblastoma and a lung cancer cell line and mouse } \\
\text { models [164]. }\end{array}$ \\
\hline Mer590 (Monoclonal antibody) & MerTK & Anti-cancer properties in lung cancer cell lines [157]. \\
\hline NPS-1034 (Small molecule) & Axl, Met & $\begin{array}{l}\text { Anti-cancer properties in EGFR inhibitor resistant lung cancer cell lines and } \\
\text { xenograft models [165]. }\end{array}$ \\
\hline Spiroindoline-based analogs (Small molecule) & Tyro3 & None reported. \\
\hline UNC569 (Small molecule) & $\begin{array}{l}\text { MerTK, Axl, } \\
\text { Tyro3 }\end{array}$ & Anti-cancer properties in ALL and AML cell lines $[146,147]$. \\
\hline UNC1062 (Small molecule) & MerTK & Anti-cancer properties AML cell lines [147]. \\
\hline UNC1666 (Small molecule) & MerTK, Flt3 & Reduces colony formation in AML cell lines [148]. \\
\hline UNC2025 (Small molecule) & MerTK, Flt3 & $\begin{array}{l}\text { Anti-cancer properties in non-small cell lung cancer, leukemia and glioblastoma } \\
\text { mouse models [152-155]. }\end{array}$ \\
\hline UNC 2250 (Small molecule) & MerTK & $\begin{array}{l}\text { Anti-cancer properties in mantle cell lymphoma cell lines and mouse models } \\
\text { [166]. }\end{array}$ \\
\hline UNC2541 (Small molecule) & MerTK & None reported. \\
\hline YW327.6S2 (Monoclonal antibody) & Axl & Anti-cancer properties in lung and breast cancer mouse models [70]. \\
\hline
\end{tabular}


FLT3 inhibitor [149]. In preclinical studies it has been demonstrated to have therapeutic effects in non-small cell lung cancer, leukemia and glioblastoma models [152-155]. Interestingly, one study focused on glioma-associated macrophages and microglia and found that UNC2025 alone and in combination with radiotherapy decreased the number of CD206+ M2 macrophages [155]. This supports the hypothesis that blocking M2 polarization via targeting TAM receptor signaling may impair disease progression. More recently, a macrocyclic pyrimidine, UNC2541, was synthesized and found be selective for MerTK over the other TAM receptors and FLT3 [156]. Mer590, a monoclonal antibody against MerTK, decreased MerTK expression in several lung cancer cell lines as well as increased apoptosis, sensitivity to carboplatin and decreased colony formation [157].

Although less studied, synthesis of Tyro3 inhibitors has also been explored (see Table 1). E/Z 6-Chloro-3-(3-trifluoromethyl-benzyliden)-1,3-dihydroindol-2-one ("Compound 47") has been shown to block Tyro3 phosphorylation HuH7 cells [158]. Additionally, spiroindoline-based and 2,4-diaminopyrimidine-5-carbox-amide inhibitors of Tyro3 have been made [159-161].

Small molecule inhibitors, antibody-drug conjugates, Axl-Fc fusion proteins and CAR-T therapies for the TAM receptors are in clinical trials. Summarized in Table 2, most clinical trials have primarily aimed to target Axl because of Axl's known role in driving disease progression through expression on cancer cells, although some inhibitors also inhibit MerTK and other RTKs with lower affinity. Active trials are in Phase I or II with some trials studying combinational effects with other cancer treatments. A Phase I clinical trial of ASLAN-002 with published results has been completed, and it was determined that $300 \mathrm{mg}$ twice daily is a well-tolerated dose and is recommended for Phase II [162]. The most commonly reported adverse events were nausea, fatigue and constipation, and atrial fibrillation was reported as a dose limiting toxicity. Cabozantinib is a multi-kinase small molecule inhibitor that targets Axl, c-Met, VEGFR2, RET, KIT, and FLT3. This therapy is FDA-approved for advanced renal cell carcinoma,

Table 2 Summary of clinical trials targeting TAM receptor activity

\begin{tabular}{|c|c|c|c|}
\hline TAM Targeting Drug (Drug Type) & Target(s) & Condition(s) & ClincialTrials.gov Identifier(s) \\
\hline AVB-S6-500 (Axl-Fc fusion protein) & Gas6 & $\begin{array}{l}\text { Ovarian Cancer } \\
\text { Epithelial Ovarian Cancer } \\
\text { Primary Peritoneal Carcinoma } \\
\text { Fallopian Tube Cancer }\end{array}$ & $\begin{array}{l}\text { NCT03401528 } \\
\text { NCT03607955 } \\
\text { NCT03639246 }\end{array}$ \\
\hline ASLAN-002/BMS-777607 (Small molecule) & Met, RON, FLT3, AxI & Advanced or Metastatic Solid Tumors & $\begin{array}{l}\text { NCT00605618 } \\
\text { NCT01721148 [162] }\end{array}$ \\
\hline BA3011/CAB-AXL-ADC (Antibody-drug conjugate) & Axl & $\begin{array}{l}\text { Solid Tumor } \\
\text { Non-Small Cell Lung Cancer } \\
\text { Castration-Resistant Prostate Cancer } \\
\text { Pancreatic Cancer }\end{array}$ & NCT03425279 \\
\hline Bemcentinib/BGB324/R428 (Small molecule) & Axl & Advanced or Metastatic Solid Tumors & $\begin{array}{l}\text { NCT02424617 } \\
\text { NCT02488408 } \\
\text { NCT02872259 } \\
\text { NCT02922777 } \\
\text { NCT03184558 } \\
\text { NCT03184571 } \\
\text { NCT03649321 } \\
\text { NCT03654833 }\end{array}$ \\
\hline BPI-9016 M (Small molecule) & Axl, Met & $\begin{array}{l}\text { Solid Tumors } \\
\text { Non-Small Cell Lung Cancer }\end{array}$ & $\begin{array}{l}\text { NCT02478866 } \\
\text { NCT02929290 }\end{array}$ \\
\hline CCT301 (CAR-T) & Axl & Renal Cell Carcinoma & NCT03393936 \\
\hline INCB081776 (Small molecule) & Axl, MerTK & Advanced Solid Tumors & NCT03522142 \\
\hline MRX-2843 (Small molecule) & MerTK, FLT3 & Advanced or Metastatic Solid Tumors & NCT03510104 \\
\hline ONO-7475 (Small molecule) & Axl, MerTK & $\begin{array}{l}\text { Advanced or Metastatic Solid Tumors } \\
\text { Acute Leukemia }\end{array}$ & $\begin{array}{l}\text { NCT03176277 } \\
\text { NCT03510104 }\end{array}$ \\
\hline TP-0903 (Small molecule) & Axl & $\begin{array}{l}\text { Advanced Solid Tumors } \\
\text { Chronic Lymphocytic Leukemia } \\
\text { Small Lymphocytic Lymphoma } \\
\text { EGFR Positive Non-small Cell Lung Cancer } \\
\text { Colorectal Carcinoma } \\
\text { Recurrent Ovarian Carcinoma } \\
\text { BRAF-Mutated Melanoma }\end{array}$ & $\begin{array}{l}\text { NCT02729298 } \\
\text { NCT03572634 }\end{array}$ \\
\hline
\end{tabular}


hepatocellular carcinoma and medullary thyroid cancer. The most commonly reported adverse events for this inhibitor are diarrhea, palmar-plantar erythrodysesthesia, fatigue, nausea, decreased appetite, hypertension, vomiting, weight loss, and constipation [163].

\section{Conclusions}

When a drug is administered, all of the cells in the microenvironment are impacted by the drug, not just the cancer cells. While current clinical trials are aimed at targeting the tumor cells, it is of interest if targeting the macrophages will contribute to the results of these trials. Given the strong evidence that the TAM receptors on macrophages have tumor-promoting roles of promoting M2 polarization and efferocytosis, it is possible that targeting the TAM receptors on macrophages will be an effective therapy for treating different types of cancers. More preclinical evidence and clinical studies with a focus on macrophages could help determine the therapeutic relevance of targeting the TAM receptors as a cancer treatment.

\section{Abbreviations}

ATP: Adenosine triphosphate; ATP11C: Adenosine triphosphatase 11C; BMDM: Bone marrow-derived macrophages; CML: Chronic myeloid leukemia; ECM: Extracellular matrix; EGF: Epidermal growth factor; FNIII: Fibronectin type III; GDP: Guanosine diphosphate; GEF: Guanine nucleotide-exchange factor; Gla: $\gamma$-carboxyglutamic acid; GM-CSF: Granulocyte-macrophage colonystimulating factor; Grb2: Growth factor receptor-bound protein 2; GSK3 $\beta$ : Glycogen synthase kinase 3 $\beta$; GTP: Guanosine triphosphate; HGF: Hepatocyte growth factor; IFN: Interferon; IgL: Immunoglobulin-like; IL: Interleukin; IPA: Invasive pulmonary aspergillosis; LG: Laminin G; LPC: Lysophosphatidylcholine; LPS: Lipopolysaccharide; LXR: Liver X receptor; M-CSF: Macrophage colony-stimulating factor; MTA: Mineral trioxide aggregate; NO: Nitric oxide; PI3K: Phosphoinositide 3 kinase; PMA: Phorbol 12-myristate 13-acetate; PPAR: Peroxisome proliferator activated receptor; PSR: Phosphatidylserine receptor; PtdSer: Phosphatidylserine; RTK: Receptor tyrosine kinase; RXR: Retinoid X receptor; S1P: Spingosine 1-phosphate; SHBP: Sex hormone binding protein; TAM Receptors: Tyro3, Axl and MerTK; TGF- $\beta$ : Transforming growth factor $\beta$; TKD: Tyrosine kinase domain; TME: Tumor microenvironment; TNF: Tumor necrosis factor; Tulp-1: Tubbylike protein 1; UTP: Uridine triphosphate; WT: Wild type; Xkr8: Xk-Related Protein 8

\section{Acknowledgements}

We would like to thank Timothy H. Phelps, Professor and Medical Illustrator at Johns Hopkins University, for generation of the figures presented in this review. We thank Amber de Groot for providing critical feedback to the manuscript. We also thank members of the Pienta Lab and the Brady Urological Institute for thoughtful feedback.

\section{Funding}

This work is supported by NCI grants U54CA143803، CA163124, CA093900, and CA143055 as well as the Prostate Cancer Foundation, the Patrick C. Walsh Fund and a gift from the Stutt family.

\section{Availability of data and materials}

Not applicable.

\section{Authors' contributions}

KVM wrote the manuscript. SRA and KJP revised the manuscript. All authors read and approved the final manuscript.

Ethics approval and consent to participate Not applicable.
Consent for publication

Not applicable.

\section{Competing interests}

The authors declare that they have no competing interests.

\section{Publisher's Note}

Springer Nature remains neutral with regard to jurisdictional claims in published maps and institutional affiliations.

\section{Author details}

'Department of Pharmacology and Molecular Sciences, The Johns Hopkins School of Medicine, Baltimore, MD, USA. ${ }^{2}$ The James Buchanan Brady Urological Institute, Department of Urology, The Johns Hopkins School of Medicine, Baltimore, MD, USA. ${ }^{3}$ Department of Oncology, The Johns Hopkins School of Medicine, Baltimore, MD, USA. ${ }^{4}$ Department of Chemical and Biomolecular Engineering, Johns Hopkins University, Baltimore, MD, USA.

Received: 4 February 2019 Accepted: 2 May 2019

Published online: 14 May 2019

\section{References}

1. Siegel RL, Miller KD, Jemal A. Cancer statistics, 2019. CA Cancer J Clin. 2019.

2. Valkenburg $\mathrm{KC}$, de Groot $\mathrm{AE}$, Pienta KJ. Targeting the tumour stroma to improve cancer therapy. Nat Rev Clin Oncol. 2018;15(6):366-81.

3. Steeg PS. Targeting metastasis. Nat Rev Cancer. 2016;16(4):201-18.

4. Sun Y. Tumor microenvironment and cancer therapy resistance. Cancer Lett. 2016;380(1):205-15.

5. Barker HE, Paget JT, Khan AA, Harrington KJ. The tumour microenvironment after radiotherapy: mechanisms of resistance and recurrence. Nat Rev Cancer. 2015;15(7):409-25.

6. Hao NB, Lu MH, Fan YH, Cao YL, Zhang ZR, Yang SM. Macrophages in tumor microenvironments and the progression of tumors. Clin Dev Immunol. 2012;2012:948098.

7. Gordon S, Martinez-Pomares L. Physiological roles of macrophages. Pflugers Arch. 2017;469(3-4):365-74.

8. Elhelu MA. The role of macrophages in immunology. J Natl Med Assoc. 1983;75(3):314-7.

9. Kodelja V, Müller C, Tenorio S, Schebesch C, Orfanos CE, Goerdt S. Differences in angiogenic potential of classically vs alternatively activated macrophages. Immunobiology. 1997;197(5):478-93.

10. Jetten N, Verbruggen S, Gijbels MJ, Post MJ, De Winther MP, Donners MM. Anti-inflammatory $M 2$, but not pro-inflammatory $M 1$ macrophages promote angiogenesis in vivo. Angiogenesis. 2014;17(1):109-18.

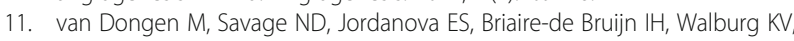
Ottenhoff TH, et al. Anti-inflammatory M2 type macrophages characterize metastasized and tyrosine kinase inhibitor-treated gastrointestinal stromal tumors. Int J Cancer. 2010;127(4):899-909.

12. Lepique AP, Daghastanli KR, Cuccovia IM, Villa LL. HPV16 tumor associated macrophages suppress antitumor T cell responses. Clin Cancer Res. 2009; 15(13):4391-400

13. Han Q, Shi H, Liu F. CD163(+) M2-type tumor-associated macrophage support the suppression of tumor-infiltrating T cells in osteosarcoma. Int Immunopharmacol. 2016;34:101-6.

14. Finkernagel F, Reinartz S, Lieber S, Adhikary T, Wortmann A, Hoffmann N, et al. The transcriptional signature of human ovarian carcinoma macrophages is associated with extracellular matrix reorganization. Oncotarget. 2016;7(46): 75339-52.

15. Vaught DB, Stanford JC, Cook RS. Efferocytosis creates a tumor microenvironment supportive of tumor survival and metastasis. Cancer Cell Microenviron. 2015;2(1).

16. Werfel TA, Cook RS. Efferocytosis in the tumor microenvironment. Semin Immunopathol. 2018.

17. Lu Q, Gore M, Zhang Q, Camenisch T, Boast S, Casagranda F, et al. Tyro-3 family receptors are essential regulators of mammalian spermatogenesis. Nature. 1999;398(6729):723-8.

18. Lu Q, Lemke G. Homeostatic regulation of the immune system by receptor tyrosine kinases of the tyro 3 family. Science. 2001;293(5528):306-11.

19. Linger RMA, Keating AK, Earp HS, Graham DK. TAM Receptor Tyrosine Kinases: Biologic Functions, Signaling, and Potential Therapeutic Targeting in Human Cancer. Advances in Cancer Research 2008. p. 35-83. 
20. Liu E, Hjelle B, Bishop JM. Transforming genes in chronic myelogenous leukemia. Proc Natl Acad Sci U S A. 1988;85(6):1952-6.

21. O'Bryan JP, Frye RA, Cogswell PC, Neubauer A, Kitch B, Prokop C, et al. Axl, a transforming gene isolated from primary human myeloid leukemia cells, encodes a novel receptor tyrosine kinase. Mol Cell Biol. 1991;11(10):5016-31.

22. Jia R, Mayer BJ, Hanafusa T, Hanafusa H. A novel oncogene, v-ryk, encoding a truncated receptor tyrosine kinase is transduced into the RPL30 virus without loss of viral sequences. J Virol. 1992;66(10):5975-87.

23. Graham DK, Dawson TL, Mullaney DL, Snodgrass HR, Earp HS. Cloning and mRNA expression analysis of a novel human protooncogene, c-mer. Cell Growth Differ. 1994;5(6):647-57.

24. Polvi A, Armstrong E, Lai C, Lemke G, Huebner K, Spritz RA, et al. The human TYRO3 gene and pseudogene are located in chromosome 15q14q25. Gene. 1993;134(2):289-93.

25. Schneider C, King RM, Philipson L. Genes specifically expressed at growth arrest of mammalian-cells. Cell. 1988;54(6):787-93.

26. Dahlback B, Villoutreix BO. Regulation of blood coagulation by the protein C anticoagulant pathway: novel insights into structure-function relationships and molecular recognition. Arterioscler Thromb Vasc Biol. 2005;25(7):1311-20.

27. Manfioletti G, Brancolini C, Avanzi G, Schneider C. The protein encoded by a growth arrest-specific gene (Gas6) is a new member of the vitamin-Kdependent proteins related to protein-S, a negative Coregulator in the blood-coagulation Cascade. Mol Cell Biol. 1993;13(8):4976-85.

28. DiScipio RG, Davie EW. Characterization of protein $\mathrm{S}$, a gammacarboxyglutamic acid containing protein from bovine and human plasma. Biochemistry. 1979;18(5):899-904.

29. Walker FJ. Regulation of activated protein $C$ by protein S. the role of phospholipid in factor Va inactivation. J Biol Chem. 1981;256(21):11128-31.

30. Lundwall A, Dackowski W, Cohen E, Shaffer M, Mahr A, Dahlback B, et al. Isolation and sequence of the CDNA for human protein $\mathrm{S}$, a regulator of blood coagulation. Proc Natl Acad Sci U S A. 1986;83(18):6716-20.

31. Varnum BC, Young C, Elliott G, Garcia A, Bartley TD, Fridell YW, et al. Axl receptor tyrosine kinase stimulated by the vitamin K-dependent protein encoded by growth-arrest-specific gene 6. Nature. 1995;373(6515):623-6.

32. Stitt TN, Conn G, Gore M, Lai C, Bruno J, Radziejewski C, et al. The anticoagulation factor protein $\mathrm{S}$ and its relative, Gas6, are ligands for the tyro 3/Axl family of receptor tyrosine kinases. Cell. 1995;80(4):661-70.

33. Lew ED, Oh J, Burrola PG, Lax I, Zagorska A, Traves PG, et al. Differential TAM receptor-ligand-phospholipid interactions delimit differential TAM bioactivities. Elife. 2014;3.

34. Nomura K, Vilalta A, Allendorf DH, Hornik TC, Brown GC. Activated microglia Desialylate and phagocytose cells via neuraminidase, Galectin-3, and Mer tyrosine kinase. J Immunol. 2017;198(12):4792-801.

35. Caberoy NB, Alvarado G, Bigcas JL, Li W. Galectin-3 is a new MerTK-specific eat-me signal. J Cell Physiol. 2012;227(2):401-7.

36. Caberoy NB, Zhou Y, Li W. Tubby and tubby-like protein 1 are new MerTK ligands for phagocytosis. EMBO J. 2010;29(23):3898-910.

37. Mark MR, Chen J, Hammonds RG, Sadick M, Godowsk PJ. Characterization of Gas6, a member of the superfamily of $\mathrm{G}$ domain-containing proteins, as a ligand for Rse and Axl. J Biol Chem. 1996;271(16):9785-9.

38. Heiring C, Dahlback B, Muller YA. Ligand recognition and homophilic interactions in Tyro3: structural insights into the Axl/Tyro3 receptor tyrosine kinase family. J Biol Chem. 2004;279(8):6952-8.

39. Tsou WI, Nguyen KQ, Calarese DA, Garforth SJ, Antes AL, Smirnov SV, et al. Receptor tyrosine kinases, TYRO3, AXL, and MER, demonstrate distinct patterns and complex regulation of ligand-induced activation. J Biol Chem. 2014;289(37):25750-63.

40. Nakano T, Ishimoto Y, Kishino J, Umeda M, Inoue K, Nagata K, et al. Cell adhesion to phosphatidylserine mediated by a product of growth arrestspecific gene 6. J Biol Chem. 1997;272(47):29411-4.

41. Zagorska A, Traves PG, Lew ED, Dransfield I, Lemke G. Diversification of TAM receptor tyrosine kinase function. Nat Immunol. 2014;15(10):920-8.

42. Kasikara C, Kumar S, Kimani S, Tsou WI, Geng K, Davra V, et al. Phosphatidylserine sensing by TAM receptors regulates AKT-dependent Chemoresistance and PD-L1 expression. Mol Cancer Res. 2017;15(6):753-64.

43. Graham DK, DeRyckere D, Davies KD, Earp HS. The TAM family: phosphatidylserine sensing receptor tyrosine kinases gone awry in cancer. Nat Rev Cancer. 2014;14(12):769-85.

44. Nelsestuen GL, Kisiel W, Di Scipio RG. Interaction of vitamin K dependent proteins with membranes. Biochemistry. 1978;17(11):2134-8.

45. Cummings CT, Deryckere D, Earp HS, Graham DK. Molecular pathways: MERTK signaling in cancer. Clin Cancer Res. 2013;19(19):5275-80.
46. Axelrod H, Pienta KJ. Axl as a mediator of cellular growth and survival. Oncotarget. 2014;5(19):1-35.

47. Fry MJ. Structure, regulation and function of phosphoinositide 3-kinases. Biochim Biophys Acta. 1994;1226(3):237-68.

48. Braunger J, Schleithoff L, Schulz AS, Kessler H, Lammers R, Ullrich A, et al. Intracellular signaling of the Ufo/Axl receptor tyrosine kinase is mediated mainly by a multi-substrate docking-site. Oncogene. 1997;14(22):2619-31.

49. Lan ZD, Wu HY, Li WQ, Wu SC, Lu L, Xu M, et al. Transforming activity of receptor tyrosine kinase Tyro3 is mediated, at least in part, by the PI3 kinase-signaling pathway. Blood. 2000;95(2):633-8.

50. Georgescu MM, Kirsch KH, Shishido T, Zong C, Hanafusa H. Biological effects of cMer receptor tyrosine kinase in hematopoietic cells depend on the Grb2 binding site in the receptor and activation of NF-kappaB. Mol Cell Biol. 1999;19(2):1171-81.

51. Weinger JG, Gohari P, Yan Y, Backer JM, Varnum B, Shafit-Zagardo B. In brain, Axl recruits Grb2 and the p85 regulatory subunit of PI3 kinase; in vitro mutagenesis defines the requisite binding sites for downstream Akt activation. J Neurochem. 2008;106(1):134-46.

52. Alciato F, Sainaghi PP, Sola D, Castello L, Avanzi GC. TNF-alpha, IL-6, and IL-1 expression is inhibited by GAS6 in monocytes/macrophages. J Leukoc Biol. 2010;87(5):869-75.

53. Vergadi $E$, leronymaki $E$, Lyroni $K$, Vaporidi $K$, Tsatsanis C. Akt signaling pathway in macrophage activation and M1/M2 polarization. J Immunol. 2017;198(3):1006-14.

54. Lu J, Xie L, Liu C, Zhang Q, Sun S. PTEN/PI3K/AKT regulates macrophage polarization in emphysematous mice. Scand J Immunol. 2017;85(6):395-405.

55. Malawista A, Wang X, Trentalange M, Allore HG, Montgomery RR. Coordinated expression of tyro3, axl, and mer receptors in macrophage ontogeny. Macrophage (Houst). 2016;3.

56. Zahuczky G, Kristof E, Majai G, Fesus L. Differentiation and glucocorticoid regulated apopto-phagocytic gene expression patterns in human macrophages. Role of Mertk in enhanced phagocytosis. PLoS One. 2011;6(6):e21349.

57. Seitz HM, Camenisch TD, Lemke G, Earp HS, Matsushima GK. Macrophages and dendritic cells use different AxI/Mertk/Tyro3 receptors in clearance of apoptotic cells. J Immunol. 2007;178(9):5635-42.

58. Shibata T, Habiel DM, Coelho AL, Kunkel SL, Lukacs NW, Hogaboam CM. Axl receptor blockade ameliorates pulmonary pathology resulting from primary viral infection and viral exacerbation of asthma. J Immunol. 2014;192(8):3569-81.

59. Waterborg CEJ, Broeren MGA, Blaney Davidson EN, Koenders MI, van Lent $P$, van den Berg WB, et al. The level of synovial $A X L$ expression determines the outcome of inflammatory arthritis, possibly depending on the upstream role of TGF-beta1. Rheumatology (Oxford). 2018;58(3):536-46.

60. Grabiec AM, Goenka A, Fife ME, Fujimori T, Hussell T. Axl and MerTK receptor tyrosine kinases maintain human macrophage efferocytic capacity in the presence of viral triggers. Eur J Immunol. 2018;48(5):855-60.

61. Zizzo G, Cohen PL. Antibody cross-linking of CD14 activates MerTK and promotes human macrophage clearance of apoptotic neutrophils: the dual role of CD14 at the crossroads between M1 and M2c polarization. Inflammation. 2018:41(6):2206-21.

62. Zizzo G, Hilliard BA, Monestier M, Cohen PL. Efficient clearance of early apoptotic cells by human macrophages requires M2C polarization and MerTK induction. J Immunol. 2012;189(7):3508-20.

63. Sanjurjo L, Aran G, Tellez E, Amezaga N, Armengol C, Lopez D, et al. CD5L promotes M2 macrophage polarization through autophagy-mediated upregulation of ID3. Front Immunol. 2018;9:480.

64. McColl A, Bournazos S, Franz S, Perretti M, Morgan BP, Haslett C, et al. Glucocorticoids induce protein S-dependent phagocytosis of apoptotic neutrophils by human macrophages. J Immunol. 2009;183(3):2167-75.

65. Camenisch TD, Koller BH, Earp HS, Matsushima GK. A novel receptor tyrosine kinase, Mer, inhibits TNF-alpha production and lipopolysaccharideinduced endotoxic shock. J Immunol. 1999;162(6):3498-503.

66. Shen Y, Cui X, Rong Y, Zhang Z, Xiao L, Zhou T, et al. Exogenous Gas6 attenuates silica-induced inflammation on differentiated THP-1 macrophages. Environ Toxicol Pharmacol. 2016;45:222-6.

67. Ubil E, Caskey L, Holtzhausen A, Hunter D, Story C, Earp HS. Tumor-secreted Pros 1 inhibits macrophage $\mathrm{M} 1$ polarization to reduce antitumor immune response. J Clin Invest. 2018;128(6):2356-69.

68. Deng T, Zhang Y, Chen Q, Yan K, Han D. Toll-like receptor-mediated inhibition of Gas6 and ProS expression facilitates inflammatory cytokine production in mouse macrophages. Immunology. 2012;135(1):40-50.

69. Shibata T, Habiel DM, Coelho AL, Hogaboam CM. Axl receptor blockade protects from invasive pulmonary aspergillosis in mice. J Immunol. 2014; 193(7):3559-65. 
70. Ye X, Li Y, Stawicki S, Couto S, Eastham-Anderson J, Kallop D, et al. An antiAxl monoclonal antibody attenuates xenograft tumor growth and enhances the effect of multiple anticancer therapies. Oncogene. 2010;29(38):5254-64.

71. Kim SY, Lim EJ, Yoon YS, Ahn YH, Park EM, Kim HS, et al. Liver X receptor and STAT1 cooperate downstream of Gas6/Mer to induce anti-inflammatory arginase 2 expression in macrophages. Sci Rep. 2016;6:29673.

72. Yeh HW, Chiang CF, Chen PH, Su CC, Wu YC, Chou L, et al. Axl involved in mineral trioxide aggregate induces macrophage polarization. J Endod. 2018.

73. Nam SH, Kim D, Lee D, Lee HM, Song DG, Jung JW, et al. Lysyl-tRNA synthetase-expressing colon spheroids induce M2 macrophage polarization to promote metastasis. J Clin Invest. 2018;128(11):5034-55.

74. Mackinnon AC, Farnworth SL, Hodkinson PS, Henderson NC, Atkinson KM, Leffler $\mathrm{H}$, et al. Regulation of alternative macrophage activation by galectin3. J Immunol. 2008;180(4):2650-8.

75. Silva MT. Secondary necrosis: the natural outcome of the complete apoptotic program. FEBS Lett. 2010;584(22):4491-9.

76. de Oliveira Fulco T, Andrade PR, de Mattos Barbosa MG, Pinto TG, Ferreira PF, Ferreira $\mathrm{H}$, et al. Effect of apoptotic cell recognition on macrophage polarization and mycobacterial persistence. Infect Immun. 2014;82(9):3968-78.

77. Leidi M, Gotti E, Bologna L, Miranda E, Rimoldi M, Sica A, et al. M2 macrophages phagocytose rituximab-opsonized leukemic targets more efficiently than $\mathrm{m} 1$ cells in vitro. J Immunol. 2009;182(7):4415-22.

78. Banerjee S, Xie N, Cui H, Tan Z, Yang S, Icyuz M, et al. MicroRNA let-7C regulates macrophage polarization. J Immunol. 2013;190(12):6542-9.

79. Heasman SJ, Giles KM, Rossi AG, Allen JE, Haslett C, Dransfield I. Interferon gamma suppresses glucocorticoid augmentation of macrophage clearance of apoptotic cells. Eur J Immunol. 2004;34(6):1752-61.

80. Elliott MR, Chekeni FB, Trampont PC, Lazarowski ER, Kadl A, Walk SF, et al. Nucleotides released by apoptotic cells act as a find-me signal to promote phagocytic clearance. Nature. 2009;461(7261):282-6.

81. Lauber K, Bohn E, Kröber SM, Xiao Y-j, Blumenthal SG, Lindemann RK, et al. Apoptotic cells induce migration of phagocytes via Caspase-3-mediated release of a lipid attraction signal. Cell. 2003;113(6):717-30.

82. Truman LA, Ford CA, Pasikowska M, Pound JD, Wilkinson SJ, Dumitriu IE, et al. CX3CL1/fractalkine is released from apoptotic lymphocytes to stimulate macrophage chemotaxis. Blood. 2008:112(13):5026-36.

83. Gude DR, Alvarez SE, Paugh SW, Mitra P, Yu J, Griffiths R, et al. Apoptosis induces expression of sphingosine kinase 1 to release sphingosine-1phosphate as a "come-and-get-me" signal. FASEB J. 2008;22(8):2629-38.

84. Suzuki J, Denning DP, Imanishi E, Horvitz HR, Nagata S. Xk-related protein 8 and CED-8 promote phosphatidylserine exposure in apoptotic cells. Science. 2013;341(6144):403-6.

85. Segawa K, Kurata S, Yanagihashi Y, Brummelkamp TR, Matsuda F, Nagata S Caspase-mediated cleavage of phospholipid flippase for apoptotic phosphatidylserine exposure. Science. 2014;344(6188):1164-8.

86. Fadok VA, Warner ML, Bratton DL, Henson PM. CD36 is required for phagocytosis of apoptotic cells by human macrophages that use either a phosphatidylserine receptor or the vitronectin receptor (alpha(v)beta(3)). J Immunol. 1998;161(11):6250-7.

87. Miyanishi M, Tada K, Koike M, Uchiyama Y, Kitamura T, Nagata S. Identification of Tim4 as a phosphatidylserine receptor. Nature. 2007:450(7168):435-9.

88. Park D, Tosello-Trampont AC, Elliott MR, Lu M, Haney LB, Ma Z, et al. BAl1 is an engulfment receptor for apoptotic cells upstream of the ELMO/Dock180/ Rac module. Nature. 2007:450(7168):430-4.

89. Fadok VA, Bratton DL, Rose DM, Pearson A, Ezekewitz RA, Henson PM. A receptor for phosphatidylserine-specific clearance of apoptotic cells. Nature. 2000;405(6782):85-90.

90. Savill J, Dransfield I, Hogg N, Haslett C. Vitronectin receptor-mediated phagocytosis of cells undergoing apoptosis. Nature. 1990;343(6254):170-3.

91. Hanayama R, Tanaka M, Miwa K, Shinohara A, Iwamatsu A, Nagata S. Identification of a factor that links apoptotic cells to phagocytes. Nature. 2002:417(6885):182-7.

92. Lemke G, Burstyn-Cohen T. TAM receptors and the clearance of apoptotic cells. Ann N Y Acad Sci. 2010;1209:23-9.

93. Mahajan NP, Earp HS. An SH2 domain-dependent, phosphotyrosineindependent interaction between Vav1 and the Mer receptor tyrosine kinase: a mechanism for localizing guanine nucleotide-exchange factor action. J Biol Chem. 2003;278(43):42596-603.

94. Crespo P, Schuebel KE, Ostrom AA, Gutkind JS, Bustelo XR. Phosphotyrosinedependent activation of Rac-1 GDP/GTP exchange by the vav protooncogene product. Nature. 1997;385(6612):169-72.
95. Kim SY, Kim S, Bae DJ, Park SY, Lee GY, Park GM, et al. Coordinated balance of Rac1 and RhoA plays key roles in determining phagocytic appetite. PLoS One. 2017;12(4):e0174603.

96. Allen WE, Zicha D, Ridley AJ, Jones GE. A role for Cdc42 in macrophage chemotaxis. J Cell Biol. 1998;141(5):1147-57.

97. Allen WE, Jones GE, Pollard JW, Ridley AJ. Rho, Rac and Cdc42 regulate actin organization and cell adhesion in macrophages. J Cell Sci. 1997;110(Pt 6): 707-20.

98. Han CZ, Ravichandran KS. Metabolic connections during apoptotic cell engulfment. Cell. 2011;147(7):1442-5.

99. Roszer T, Menendez-Gutierrez MP, Cedenilla M, Ricote M. Retinoid X receptors in macrophage biology. Trends Endocrinol Metab. 2013; 24(9):460-8.

100. Kimura T, Nada S, Takegahara N, Okuno T, Nojima S, Kang S, et al. Polarization of M2 macrophages requires Lamtor1 that integrates cytokine and amino-acid signals. Nat Commun. 2016;7:13130.

101. Gallardo-Soler A, Gomez-Nieto C, Campo ML, Marathe C, Tontonoz P, Castrillo A, et al. Arginase I induction by modified lipoproteins in macrophages: a peroxisome proliferator-activated receptor-gamma/deltamediated effect that links lipid metabolism and immunity. Mol Endocrinol. 2008:22(6):1394-402.

102. Odegaard JI, Ricardo-Gonzalez RR, Goforth MH, Morel CR, Subramanian V, Mukundan L, et al. Macrophage-specific PPARgamma controls alternative activation and improves insulin resistance. Nature. 2007;447(7148):1116-20.

103. Bouhlel MA, Derudas B, Rigamonti E, Dievart R, Brozek J, Haulon S, et al. PPARgamma activation primes human monocytes into alternative M2 macrophages with anti-inflammatory properties. Cell Metab. 2007;6(2): $137-43$

104. Penas F, Mirkin GA, Vera M, Cevey A, Gonzalez CD, Gomez Ml, et al. Treatment in vitro with PPARalpha and PPARgamma ligands drives M1-toM2 polarization of macrophages from T. cruzi-infected mice. Biochim Biophys Acta. 2015:1852(5):893-904.

105. Voll RE, Herrmann M, Roth EA, Stach C, Kalden JR, Girkontaite I. Immunosuppressive effects of apoptotic cells. Nature. 1997;390(6658):350-1.

106. Stanford JC, Young C, Hicks D, Owens P, Williams A, Vaught DB, et al. Efferocytosis produces a prometastatic landscape during postpartum mammary gland involution. J Clin Invest. 2014;124(11):4737-52.

107. Piraghaj MG, Soudi S, Ghanbarian H, Bolandi Z, Namaki S, Hashemi SM. Effect of efferocytosis of apoptotic mesenchymal stem cells (MSCs) on C57BL/6 peritoneal macrophages function. Life Sci. 2018.

108. Savage JC, Jay T, Goduni E, Quigley C, Mariani MM, Malm T, et al. Nuclear receptors license phagocytosis by trem $2+$ myeloid cells in mouse models of Alzheimer's disease. J Neurosci. 2015;35(16):6532-43.

109. Majai G, Sarang Z, Csomos K, Zahuczky G, Fesus L. PPARgamma-dependent regulation of human macrophages in phagocytosis of apoptotic cells. Eur J Immunol. 2007;37(5):1343-54.

110. Roszer T, Menendez-Gutierrez MP, Lefterova MI, Alameda D, Nunez V, Lazar MA, et al. Autoimmune kidney disease and impaired engulfment of apoptotic cells in mice with macrophage peroxisome proliferator-activated receptor gamma or retinoid $X$ receptor alpha deficiency. J Immunol. 2011; 186(1):621-31.

111. Mukundan L, Odegaard JI, Morel CR, Heredia JE, Mwangi JW, RicardoGonzalez RR, et al. PPAR-delta senses and orchestrates clearance of apoptotic cells to promote tolerance. Nat Med. 2009;15(11):1266-72.

112. Zizzo G, Cohen PL. The PPAR-gamma antagonist GW9662 elicits differentiation of M2C-like cells and upregulation of the MerTK/Gas6 axis: a key role for PPAR-gamma in human macrophage polarization. J Inflamm (Lond). 2015;12:36.

113. N AG, Bensinger SJ, Hong C, Beceiro S, Bradley MN, Zelcer N, et al. Apoptotic cells promote their own clearance and immune tolerance through activation of the nuclear receptor LXR. Immunity. 2009;31(2):245-58.

114. Choi JY, Seo JY, Yoon YS, Lee YJ, Kim HS, Kang JL. Mer signaling increases the abundance of the transcription factor LXR to promote the resolution of acute sterile inflammation. Sci Signal. 2015;8(365):ra21.

115. Morimoto K, Amano H, Sonoda F, Baba M, Senba M, Yoshimine $H$, et al. Alveolar macrophages that phagocytose apoptotic neutrophils produce hepatocyte growth factor during bacterial pneumonia in mice. Am J Resp Cell Mol. 2001;24(5):608-15.

116. Park HJ, Baen JY, Lee YJ, Choi YH, Kang JL. The TAM-family receptor Mer mediates production of HGF through the RhoA-dependent pathway in response to apoptotic cells. Mol Biol Cell. 2012;23(16):3254-65. 
117. Park HJ, Choi YH, Cho YJ, Henson PM, Kang JL. RhoA-mediated signaling up-regulates hepatocyte growth factor gene and protein expression in response to apoptotic cells. J Leukoc Biol. 2011;89(3):399-411.

118. Lee YJ, Park HJ, Woo SY, Park EM, Kang JL. RhoA/phosphatidylinositol 3kinase/protein kinase B/mitogen-activated protein kinase signaling after growth arrest-specific protein 6/mer receptor tyrosine kinase engagement promotes epithelial cell growth and wound repair via upregulation of hepatocyte growth factor in macrophages. J Pharmacol Exp Ther. 2014; 350(3):563-77.

119. Goetsch L, Caussanel V, Corvaia N. Biological significance and targeting of c-met tyrosine kinase receptor in cancer. Front Biosci (Landmark Ed). 2013;18:454-73.

120. Scott RS, McMahon EJ, Pop SM, Reap EA, Caricchio R, Cohen PL, et al. Phagocytosis and clearance of apoptotic cells is mediated by MER. Nature. 2001;411(6834):207-11

121. Subramanian M, Hayes CD, Thome JJ, Thorp E, Matsushima GK, Herz J, et al. An AXL/LRP-1/RANBP9 complex mediates DC efferocytosis and antigen cross-presentation in vivo. J Clin Invest. 2014;124(3):1296-308.

122. Zhang MY, He YF, Sun XJ, Li Q, Wang WJ, Zhao AM, et al. A high M1/M2 ratio of tumor-associated macrophages is associated with extended survival in ovarian cancer patients. J Ovarian Res. 2014;7.

123. Barros MH, Segges P, Vera-Lozada G, Hassan R, Niedobitek G. Macrophage polarization reflects T cell composition of tumor microenvironment in pediatric classical Hodgkin lymphoma and has impact on survival. PLoS One. 2015;10(5):e0124531.

124. Xu J, Escamilla J, Mok S, David J, Priceman S, West B, et al. CSF1R signaling blockade stanches tumor-infiltrating myeloid cells and improves the efficacy of radiotherapy in prostate cancer. Cancer Res. 2013;73(9):2782-94.

125. Seifert L, Werba G, Tiwari S, Giao Ly NN, Nguy S, Alothman S, et al. Radiation therapy induces macrophages to suppress T-cell responses against pancreatic tumors in mice. Gastroenterology. 2016;150(7):1659-72 e5.

126. Shiao SL, Ruffell B, DeNardo DG, Faddegon BA, Park CC, Coussens LM. TH2polarized CD4(+) T cells and macrophages limit efficacy of radiotherapy. Cancer Immunol Res. 2015;3(5):518-25.

127. Crittenden MR, Baird J, Friedman D, Savage T, Uhde L, Alice A, et al. Mertk on tumor macrophages is a therapeutic target to prevent tumor recurrence following radiation therapy. Oncotarget. 2016;7(48):78653-66.

128. Cook RS, Jacobsen KM, Wofford AM, DeRyckere D, Stanford J, Prieto AL, et al. MerTK inhibition in tumor leukocytes decreases tumor growth and metastasis. J Clin Invest. 2013;123(8):3231-42.

129. Vajkoczy P, Knyazev P, Kunkel A, Capelle HH, Behrndt S, von Tengg-Kobligk $H$, et al. Dominant-negative inhibition of the Axl receptor tyrosine kinase suppresses brain tumor cell growth and invasion and prolongs survival. Proc Natl Acad Sci U S A. 2006;103(15):5799-804.

130. Liu R, Gong M, Li X, Zhou Y, Gao W, Tulpule A, et al. Induction, regulation, and biologic function of $\mathrm{AxI}$ receptor tyrosine kinase in Kaposi sarcoma. Blood. 2010;116(2):297-305

131. Ou WB, Corson JM, Flynn DL, Lu WP, Wise SC, Bueno R, et al. AXL regulates mesothelioma proliferation and invasiveness. Oncogene. 2011;30(14):1643-52.

132. Linger RM, Cohen RA, Cummings CT, Sather S, Migdall-Wilson J, Middleton $\mathrm{DH}$, et al. Mer or Axl receptor tyrosine kinase inhibition promotes apoptosis, blocks growth and enhances chemosensitivity of human non-small cell lung cancer. Oncogene. 2013;32(29):3420-31.

133. Lee C. Overexpression of Tyro3 receptor tyrosine kinase leads to the acquisition of taxol resistance in ovarian cancer cells. Mol Med Rep. 2015; 12(1):1485-92

134. Ekyalongo RC, Mukohara T, Funakoshi Y, Tomioka H, Kataoka Y, Shimono Y, et al. TYRO3 as a potential therapeutic target in breast Cancer. Anticancer Res. 2014;34(7):3337-45.

135. Ekyalongo RC, Mukohara T, Kataoka Y, Funakoshi Y, Tomioka H, Kiyota N, et al. Mechanisms of acquired resistance to insulin-like growth factor 1 receptor inhibitor in MCF-7 breast cancer cell line. Investig New Drugs. 2013;31(2):293-303.

136. Xie SZ, Li YW, Li XY, Wang LX, Yang N, Wang YD, et al. Mer receptor tyrosine kinase is frequently overexpressed in human non-small cell lung cancer, confirming resistance to erlotinib. Oncotarget. 2015;6(11):9206-19.

137. McDaniel NK, Cummings $C T$, lida M, Hulse J, Pearson HE, Vasileiadi $E_{\text {, et al }}$ MERTK mediates intrinsic and adaptive resistance to AXL-targeting agents. Mol Cancer Ther. 2018

138. Holland SJ, Pan A, Franci C, Hu Y, Chang B, Li W, et al. R428, a selective small molecule inhibitor of Axl kinase, blocks tumor spread and prolongs survival in models of metastatic breast cancer. Cancer Res. 2010;70(4):1544-54.
139. Hector A, Montgomery EA, Karikari C, Canto M, Dunbar KB, Wang JS, et al. The Axl receptor tyrosine kinase is an adverse prognostic factor and a therapeutic target in esophageal adenocarcinoma. Cancer Biol Ther. 2010; 10(10):1009-18.

140. Ghosh AK, Secreto C, Boysen J, Sassoon T, Shanafelt TD, Mukhopadhyay D, et al. The novel receptor tyrosine kinase Axl is constitutively active in B-cell chronic lymphocytic leukemia and acts as a docking site of nonreceptor kinases: implications for therapy. Blood. 2011;117(6):1928-37.

141. Giles KM, Kalinowski FC, Candy PA, Epis MR, Zhang PM, Redfern AD, et al. Axl mediates acquired resistance of head and neck cancer cells to the epidermal growth factor receptor inhibitor erlotinib. Mol Cancer Ther. 2013; 12(11):2541-58

142. Bansal N, Mishra PJ, Stein M, DiPaola RS, Bertino JR. Axl receptor tyrosine kinase is up-regulated in metformin resistant prostate cancer cells. Oncotarget. 2015;6(17):15321-31.

143. Ben-Batalla I, Erdmann $R$, Jorgensen $H$, Mitchell $R$, Ernst $T$, von Amsberg $G$ et al. Axl blockade by BGB324 inhibits BCR-ABL tyrosine kinase inhibitorsensitive and -resistant chronic myeloid leukemia. Clin Cancer Res. 2017; 23(9):2289-300.

144. Palisoul ML, Quinn JM, Schepers E, Hagemann IS, Guo L, Reger K, et al. Inhibition of the receptor tyrosine kinase $A X L$ restores paclitaxel Chemosensitivity in uterine serous Cancer. Mol Cancer Ther. 2017;16(12):2881-91.

145. Liu J, Zhang W, Stashko MA, Deryckere D, Cummings CT, Hunter D, et al. UNC1062, a new and potent Mer inhibitor. Eur J Med Chem. 2013;65:83-93.

146. Christoph S, Deryckere D, Schlegel J, Frazer JK, Batchelor LA, Trakhimets AY, et al. UNC569, a novel small-molecule mer inhibitor with efficacy against acute lymphoblastic leukemia in vitro and in vivo. Mol Cancer Ther. 2013; 12(11):2367-77.

147. Koda $Y$, Itoh M, Tohda S. Effects of MERTK inhibitors UNC569 and UNC1062 on the growth of acute myeloid Leukaemia cells. Anticancer Res. 2018;38(1): 199-204.

148. Lee-Sherick AB, Zhang W, Menachof KK, Hill AA, Rinella S, Kirkpatrick G, et al. Efficacy of a Mer and Flt3 tyrosine kinase small molecule inhibitor, UNC1666, in acute myeloid leukemia. Oncotarget. 2015;6(9):6722-36.

149. Zhang W, DeRyckere D, Hunter D, Liu J, Stashko MA, Minson KA, et al. UNC2025, a potent and orally bioavailable MER/FLT3 dual inhibitor. J Med Chem. 2014;57(16):7031-41.

150. Zhang W, Zhang D, Stashko MA, DeRyckere D, Hunter D, Kireev D, et al. Pseudo-cyclization through intramolecular hydrogen bond enables discovery of pyridine substituted pyrimidines as new Mer kinase inhibitors. J Med Chem. 2013;56(23):9683-92.

151. Sayama A, Okado K, Nakamura K, Kawaguchi T, Iguchi T, Makino T, et al. UNC569-induced morphological changes in pigment epithelia and photoreceptor cells in the retina through MerTK inhibition in mice. Toxicol Pathol. 2018;46(2):193-201.

152. Cummings CT, Zhang W, Davies KD, Kirkpatrick GD, Zhang D, DeRyckere D, et al. Small molecule inhibition of MERTK is efficacious in non-small cell lung Cancer models independent of driver oncogene status. Mol Cancer Ther. 2015;14(9):2014-22.

153. Sufit A, Lee-Sherick AB, DeRyckere D, Rupji M, Dwivedi B, Varella-Garcia M, et al MERTK inhibition induces polyploidy and promotes cell death and cellular senescence in glioblastoma Multiforme. PLoS One. 2016;11(10):e0165107.

154. DeRyckere D, Lee-Sherick AB, Huey MG, Hill AA, Tyner JW, Jacobsen KM, et al. UNC2025, a MERTK small-molecule inhibitor, is therapeutically effective alone and in combination with methotrexate in leukemia models. Clin Cancer Res. 2017;23(6):1481-92.

155. Wu J, Frady LN, Bash RE, Cohen SM, Schorzman AN, Su YT, et al. MerTK as a therapeutic target in glioblastoma. Neuro-Oncology. 2018;20(1):92-102.

156. Mclver AL, Zhang W, Liu Q, Jiang X, Stashko MA, Nichols J, et al. Discovery of macrocyclic pyrimidines as MerTK-specific inhibitors. ChemMedChem. 2017;12(3):207-13.

157. Cummings CT, Linger RM, Cohen RA, Sather S, Kirkpatrick GD, Davies KD, et al. Mer590, a novel monoclonal antibody targeting MER receptor tyrosine kinase, decreases colony formation and increases chemosensitivity in nonsmall cell lung cancer. Oncotarget. 2014;5(21):10434-45.

158. Ho HK, Chua BT, Wong W, Lim KS, Teo V, Ong HT, et al. Benzylideneindolinones are effective as multi-targeted kinase inhibitor therapeutics against hepatocellular carcinoma. Mol Oncol. 2014;8(7):1266-77.

159. Powell NA, Hoffman JK, Ciske FL, Kaufman MD, Kohrt JT, Quin J 3rd, et al. Highly selective 2,4-diaminopyrimidine-5-carboxamide inhibitors of sky kinase. Bioorg Med Chem Lett. 2013;23(4):1046-50. 
160. Powell NA, Hoffman JK, Ciske FL, Kohrt JT, Baxi SM, Peng YW, et al. Optimization of highly selective 2,4-diaminopyrimidine-5-carboxamide inhibitors of sky kinase. Bioorg Med Chem Lett. 2013;23(4):1051-5.

161. Powell NA, Kohrt JT, Filipski KJ, Kaufman M, Sheehan D, Edmunds JE, et al. Novel and selective spiroindoline-based inhibitors of sky kinase. Bioorg Med Chem Lett. 2012;22(1):190-3.

162. Roohullah A, Cooper A, Lomax AJ, Aung J, Barge A, Chow L, et al. A phase I trial to determine safety and pharmacokinetics of ASLAN002, an oral MET superfamily kinase inhibitor, in patients with advanced or metastatic solid cancers. Investig New Drugs. 2018.

163. Singh H, Brave M, Beaver JA, Cheng J, Tang S, Zahalka E, et al. U.S. Food and Drug Administration approval: Cabozantinib for the treatment of advanced renal cell carcinoma. Clin Cancer Res. 2017;23(2):330-5.

164. Cerchia L, Esposito CL, Camorani S, Rienzo A, Stasio L, Insabato L, et al. Targeting Axl with an high-affinity inhibitory aptamer. Mol Ther. 2012;20(12): 2291-303.

165. Rho JK, Choi YJ, Kim SY, Kim TW, Choi EK, Yoon SJ, et al. MET and AXL inhibitor NPS-1034 exerts efficacy against lung cancer cells resistant to EGFR kinase inhibitors because of MET or AXL activation. Cancer Res. 2014;74(1): 253-62.

166. Shi C, Li X, Wang X, Ding N, Ping L, Shi Y, et al. The proto-oncogene Mer tyrosine kinase is a novel therapeutic target in mantle cell lymphoma. J Hematol Oncol. 2018;11(1):43.

Ready to submit your research? Choose BMC and benefit from:

- fast, convenient online submission

- thorough peer review by experienced researchers in your field

- rapid publication on acceptance

- support for research data, including large and complex data types

- gold Open Access which fosters wider collaboration and increased citations

- maximum visibility for your research: over $100 \mathrm{M}$ website views per year

At BMC, research is always in progress.

Learn more biomedcentral.com/submissions 